INTERNATIONAL DESIGN CONFERENCE - DESIGN 2018

https://doi.org/10.21278/idc.2018.0152

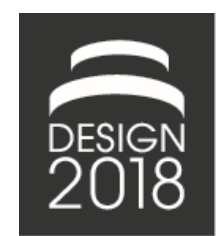

\title{
DESIGN AND FRUGAL INNOVATIONS: THREE ROLES OF RESOURCE-POOR PEOPLE
}

\author{
S. Jagtap and T. Larsson
}

\begin{abstract}
Design is imperative to satisfy needs of people in resource-limited societies. Many design studies have been carried out in the context of such societies in developing countries, and are discussed under names such as humanitarian engineering, frugal innovations, appropriate technology, design at the Base of the Pyramid, design for development, etc. In this paper, we review a wide range of literature, with close analysis of 30 design studies in this field to understand how marginalised people were engaged and positioned in those studies and to plan for future research in this field.
\end{abstract}

Keywords: social innovation, design research, co-design, frugal innovation, poverty

\section{Introduction}

While forty percent of the world population lives on less than 2 dollars a day, twenty percent subsists on less than 1.25 dollars per day, living in extreme poverty in urban slums, rural villages or shanty towns, with irregular and unpredictable income (World Bank, 2010). Poverty is still a tenacious problem with causes and effects at institutional and structural levels. Whilst Mahatma Gandhi referred to poverty as 'the worst form of violence', Amartya Sen defines it as a lack of freedom to make life choices (Sen, 1999). Others again define poverty as - hunger, violation of dignity, unemployment, gender inequality, or ill-health (e.g. Narayan et al., 2000). The people living in poverty lack access to financial and other resources, with an urgent and pressing need for immediate consumption, hampering their ability to save or invest. They often lack access to basic services and facilities such as education, public health, clean water, sanitation, infrastructure and security (Karelis 2007; Baumgartner et al., 2007).

Design, with its central idea of changing an existing situation into a desired situation (Simon, 1996), has a significant role in fulfilling unmet or under-served needs of poor people living in resource-limited societies (Papanek and Fuller, 1972). Alleviating poverty or satisfying needs of marginalised people demands designing, developing and implementing appropriate interventions, which may manifest in the form of products, services or product service systems to support social and human development of marginalised communities (e.g. Jagtap et al., 2017). Some examples of such interventions or products are medical devices, smokeless cookstoves, income-generating products or services, financial services such as microcredit (De Mel et al., 2012), state policy to support agriculture and water distribution (e.g. Buse et al., 2009; Angelin et al., 2014), vaccination plans (e.g. Marmot et al., 2008), communication products, educational devices, or any other products that enhance development of marginalised people or enhance their capabilities. The design of such interventions and products is carried out, for example, by governments as their responsibility to deliver basic public services, by NGOs as a charity or social service, by businesses as their persistent exploration and tapping of new markets, or by disadvantaged people for their livelihood (e.g. Prahalad, 2004; Karnani, 2011; Nielsen and Santos, 2013; Jagtap et al., 2017). 
Whilst design studies are typically undertaken in developed countries or affluent markets, many design investigations have also been carried out in the context of marginalised communities in developing countries (e.g. Donaldson, 2006; Jagtap et al., 2013). This design research into marginalised societies in developing countries is undertaken and discussed using many different names such as 'design for extreme affordability', 'frugal innovations', 'community development engineering', 'appropriate technology', 'humanitarian engineering', 'design at the Base of the Pyramid', 'design for development', etc. (e.g. Wicklein, 1998; Margolin, 2007; Nielsen, 2008; Donaldson, 2009; Falcioni, 2011; Jagtap et al., 2017). Moreover, interest in this subject has grown over the past decade, with several universities offering projects or courses while undertaking design research in this area (e.g. Falcioni, 2011; Jagtap et al., 2014a). Whilst many design studies have been undertaken in this field, an overview of how marginalised people were engaged and positioned in such studies is absent. There is a need to scrutinize the literature to better understand the roles of poor people in relation to the design process, i.e. whether the products are designed for them, by them, or with them. This is addressed by reviewing the relevant literature, focussing on the roles of resource-poor individuals (i.e. whether the products are designed for them, by them, or with them) - this is important for undertaking further design research in this field as well as for developing and assessing methods and tools to support the practice and education of designing products and services for marginalised communities.

Following this introduction, the paper is structured as follows. Section 2 presents an overview of design research in resource-poor societies, including its progress in recent years. Section 3 presents the research methodology employed. Section 4 discusses three roles of the marginalised people as revealed in this review - as consumers, as producers and as co-designers. Finally, Section 5 presents summary and conclusions, together with recommendations for future research in this field. As such, the paper will be useful to those who are new as well as to those who are experts in this field.

\section{Design and resource-limited societies: An overview}

The idea of employing design to enhance life circumstances of marginalised people can be tracked to 'Design for the Real World' and 'Appropriate Technology' movements, articulated by Victor Papanek and E. F. Schumacher, respectively, in the 1970s (Papanek and Fuller, 1972; Schumacher, 1973). In his book 'Design for the Real World', Papanek, an industrial designer, advised designers to address difficulties faced by the people in developing countries. The idea of Appropriate Technology (AT) was initially proposed by the economist E.F. Schumacher, and was a foundation for his book, titled 'Small is Beautiful'. Failures in transferring technologies from the industrialised world to developing countries in the 1950s and 1960s promoted the AT movement. The technologies, initially designed for the industrialised world, were not suitable for developing countries due to significant differences in political, cultural, social and other circumstances (Nieusma and Riley, 2010).

Many case studies have identified design requirements that should to be considered in designing ATs (e.g. Rohwedder, 1987; Murphy et al., 2009). Such design requirements for example, include low-cost, simplicity, use of local materials, energy efficient, small-scale, labour intensive to generate employment opportunities, maintainable by local people, and appropriate for social and cultural contexts (e.g. Wicklein, 1998; Akubue, 2000). Although the AT movement became popular, ATs failed to deliver widespread and sustainable impact in alleviating problems of marginalised people in developing countries (Murphy et al., 2009).

While the role of NGOs in carrying out design tasks is tacit in the above concepts proposed by Papanek and Schumacher (Donaldson, 2006), the role of multinational corporations (MNCs) is explicit in the Base of the Pyramid (BOP) concept proposed by Prahalad. In 1998-1999, C. K. Prahalad and his colleagues proposed that MNCs can raise their profits, while reducing poverty (Prahalad and Lieberthal, 1998; Prahalad and Hart, 1999). Contrasting the typical views of perceiving little potential for private companies in engaging with the marginalised people on a mutually positive basis, Prahalad and his colleagues argued that MNCs can enhance their profits, while fulfilling needs of resource-limited societies. Prahalad's idea of BOP markets is also discussed as subsistence marketplaces, recognising them as tightly-knit communities, which use social and informal ways of economic and other exchanges (Viswanathan and Rosa, 2007; Viswanathan et al., 2011). Viswanathan et al. (2011) advocate using insights about life circumstances of the individuals and families in these marketplaces and interactions 
between them in designing products. Similar to the AT concept, the BOP concept has also been critiqued, especially by Karnani (2007), who suggests that many products, claimed to be designed for BOP markets, are sold to the rising middle class in developing countries (Karnani, 2007).

In recent years, research on the design of low-cost, affordable innovations using a variety of names such as 'jugaad innovation' (Radjou et al., 2012), 'frugal innovation' (e.g. Zeschky et al., 2011; Radjou et al., 2012) and 'grass root innovation' (Gupta, 2016) is evolving. Such innovations typically consider designing affordable and low-cost products in a resource-limited setting (e.g. Cunha et al., 2014). While these types of products are usually less advanced technologically, they are recognised as good enough to fulfil core functions (Agnihotri, 2015). In addition to low-cost innovations and the BOP concept, analogous concepts employing names such as social innovation, social entrepreneurship, community development engineering, design for extreme affordability, humanitarian engineering and engineering for development are growing (e.g. Nielsen, 2008; Donaldson, 2009; Falcioni, 2011). Engineering and design departments in many universities around the world support and undertake development projects, while offering courses and even entire programs in such fields (Nieusma and Riley, 2010; Jagtap et al., 2014a). This has led to many design studies in the context of resource limited societies in developing countries (e.g. Whitney and Kelkar, 2004; Sethia, 2005; Hussain et al., 2012; Mattson and Wood, 2014).

\section{Research methodology}

Design investigations in the context of resource-limited societies have been carried out in many developing countries, while engaging and positioning marginalised people in different roles in relation to the design process. The term 'roles of the poor people', as used in this paper, refers to how poor people are positioned or engaged in relation to the design process, i.e. whether the design activities are undertaken by them, for them (i.e. a product is designed for them), or with them. The present paper examines these roles of poor people by discussing a broad range of studies, with close analysis of 30 papers. This literature is analysed to identify whether the products are designed for the poor people, by the poor people or with the poor people. Of the 30 papers, 25 are journal and 5 are conference papers. The journal papers were from outlets such as 'Engineering Studies', 'Research in Engineering Design', 'Technology in Society', 'Design Studies', 'Co-Design', 'Design Management Review', 'International Journal of Design', 'Journal of Product Innovation Management', 'Journal of Mechanical Design', 'Design Issues', etc. The 30 articles present studies that have been undertaken from design perspective, e.g. studies aimed at understanding and supporting how products are designed in the context of resourcepoor settings. This selection of articles allowed a focused approach, permitting their close analysis.

\section{Roles of marginalised people}

The following three roles emerge from this review: marginalised people as consumers, as producer and as co-designers. These roles are discussed in the subsections that follow, with these subsections summarised in Table 1.

\subsection{As consumers}

Poor people in resource-limited societies can simply be consumers of products. Prahalad's (2004) BOP concept mainly focuses on these people as consumers of products, arguing that private companies can make profits by selling products to them, and can contribute toward poverty alleviation by satisfying needs of people living in poverty. Products can be sold to these disadvantaged people in two ways (Jagtap and Larsson, 2013). First is about entering markets of the poor with the sole aim of making profits. Karnani (2011) has rigorously argued that this approach is not sustainable, even suggesting that it can exploit people living in poverty. Second is about selling appropriate products to the poor, with the main goal of contributing toward human and social development of resource limited societies.

Karnani (2011) presents four product categories, employing two by two matrix, with one side of the matrix illustrating if products are harmful or beneficial to the poor and other side showing if selling products to the marginalised people is profitable or not profitable (see Figure 1). An example in the matrix cell - products are beneficial to the marginalised people and profitable for companies - is mobile phones, and in the cell - products are harmful to the marginalised people but profitable for companies 
- is cigarettes. Likewise, he presents examples in the remaining two categories, advocating for the need of government regulation if products are harmful to the poor, and of innovative business models or subsidies if products are beneficial for the poor but not profitable for companies.

Table 1. Three roles of marginalised people as identified, interpreted from the articles. Legend: ' $X$ ' -role of the marginalised people could be identified, interpreted; Cons. - Consumers; Prod. - producers; Co-d. - Co-designers

\begin{tabular}{|c|c|c|c|c|c|c|c|c|c|}
\hline$\#$ & Author, year & Cons. & Prod. & Co-d. & \# & Author, year & Cons. & Prod. & Co-d. \\
\hline 1 & $\begin{array}{l}\text { Guimarges et al. } \\
\text { (1996) }\end{array}$ & & $\mathrm{X}$ & & 16 & $\begin{array}{l}\text { Nieusma and } \\
\text { Riley (2010) }\end{array}$ & $X$ & & $\mathrm{X}$ \\
\hline 2 & Wicklein (1998) & $X$ & & & 17 & Hussain (2010) & $\mathrm{X}$ & & $X$ \\
\hline 3 & $\begin{array}{l}\text { Whitney and } \\
\text { Kelkar (2004) }\end{array}$ & $\mathrm{X}$ & & & 18 & $\begin{array}{l}\text { Viswanathan et } \\
\text { al. (2011) }\end{array}$ & $\mathrm{X}$ & & \\
\hline 4 & Girón et al. (2004) & & $X$ & $X$ & 19 & $\begin{array}{l}\text { Hussain et al. } \\
(2012)\end{array}$ & $\mathrm{X}$ & & $\mathrm{X}$ \\
\hline 5 & Amir (2004) & $\mathrm{X}$ & $X$ & $\mathrm{X}$ & 20 & $\begin{array}{l}\text { Viswanathan } \\
\text { and Sridharan } \\
(2012)\end{array}$ & $\mathrm{X}$ & $\mathrm{X}$ & $X$ \\
\hline 6 & Sethia (2005) & $X$ & & $X$ & 21 & Crabbe (2012) & $\mathrm{X}$ & $\mathrm{X}$ & $X$ \\
\hline 7 & $\begin{array}{l}\text { Rodriguez et al. } \\
(2006)\end{array}$ & $\mathrm{X}$ & & & 22 & $\begin{array}{l}\text { Austin- } \\
\text { Breneman and } \\
\text { Yang (2013) }\end{array}$ & & $\mathrm{X}$ & \\
\hline 8 & Donaldson (2006) & & $\mathrm{X}$ & & 23 & $\begin{array}{l}\text { Jagtap and } \\
\text { Larsson (2013) }\end{array}$ & $\mathrm{X}$ & & $\mathrm{X}$ \\
\hline 9 & Thomas (2006) & $\mathrm{X}$ & $\mathrm{X}$ & $\mathrm{X}$ & 24 & $\begin{array}{l}\text { Mattson and } \\
\text { Wood (2014) }\end{array}$ & $\mathrm{X}$ & & $X$ \\
\hline 10 & Murcott (2007) & $\mathrm{X}$ & $X$ & & 25 & $\begin{array}{l}\text { Jagtap et al. } \\
(2014 a)\end{array}$ & $\mathrm{X}$ & & \\
\hline 11 & $\begin{array}{l}\text { Ramachandran et } \\
\text { al. (2007) }\end{array}$ & $\mathrm{X}$ & & $\mathrm{X}$ & 26 & $\begin{array}{l}\text { Manen et al. } \\
\text { (2015) }\end{array}$ & $\mathrm{X}$ & & $X$ \\
\hline 12 & Cai et al. (2007) & $\mathrm{X}$ & & $X$ & 27 & Kang (2016) & & $X$ & $X$ \\
\hline 13 & $\begin{array}{l}\text { Jiehui and } \\
\text { Kandachar (2008) }\end{array}$ & $\mathrm{X}$ & & $\mathrm{X}$ & 28 & $\begin{array}{l}\text { Ambole et al. } \\
(2016)\end{array}$ & $\mathrm{X}$ & & $\mathrm{X}$ \\
\hline 14 & $\begin{array}{l}\text { Murphy et al. } \\
(2009)\end{array}$ & $\mathrm{X}$ & & $X$ & 29 & $\begin{array}{l}\text { Aranda Jan et al. } \\
\text { (2016) }\end{array}$ & $X$ & & \\
\hline 15 & Donaldson (2009) & $X$ & $X$ & $X$ & 30 & $\begin{array}{l}\text { Ssozi-Mugarura } \\
\text { et al. (2017) }\end{array}$ & $X$ & & $X$ \\
\hline
\end{tabular}

As consumers, many articles present examples of a diverse range of products and services, including, among others, medical devices (Aranda Jan et al., 2016), cook stoves (e.g. Murphy et al., 2009), clean drinking water (Whitney and Kelkar, 2004), access to healthcare services (Jiehui and Kandachar, 2008; Jagtap et al., 2014a), ICT services (e.g. Cai et al., 2007) and sanitation (Ambole et al., 2016). These examples typically represent products or services that are beneficial for the poor. Thomas (2006) presents many examples of products designed for selling to poor people, e.g. clockwork radio, solarlanterns, fuel-efficient cook stoves, and power systems. Several studies do not present information on the aspects of financial sustainability which is essential to sell products to the poor or provide them access to the functions afforded by the products, although a few studies have taken into account such aspects of financial sustainability. For example, Jagtap and Kandachar (2010) present a case study on irrigation system designed for low-income and deprived farmers, reporting on how microcredit and subsidies enabled those farmers to purchase the irrigation system and how aspects of financial sustainability were taken into account and implemented in the design process. In a similar fashion, Jagtap and Larsson (2013) present a study on the process of designing a healthcare system to monitor 
health conditions of children from resource limited societies and how aspects of financial sustainability were implemented in the process. Another example is the holistic contextual design framework, developed by Aranda Jan et al. (2016), aimed at assisting designers to consider such aspects in the initial phases of the design process.

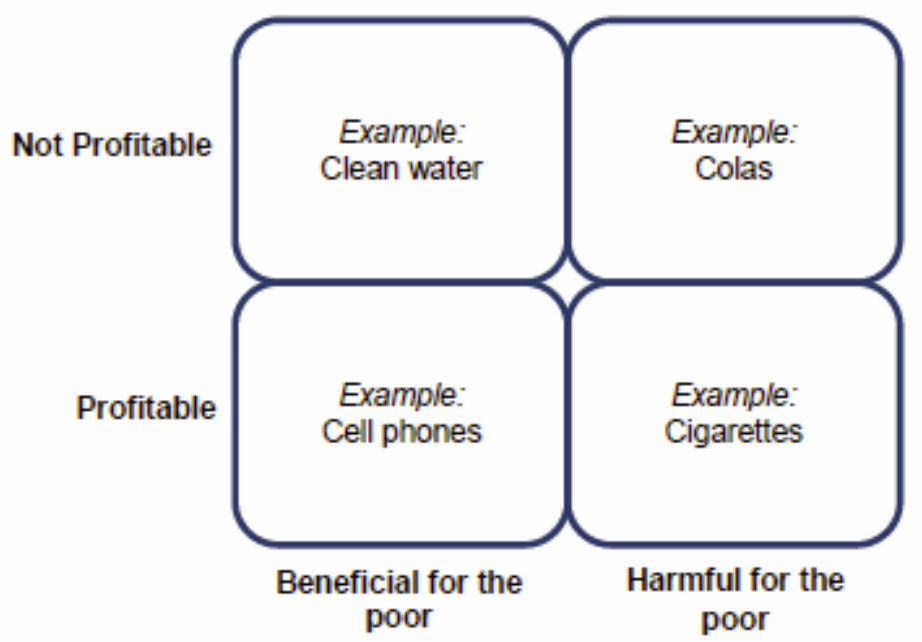

Figure 1. Four categories of products for marginalised people (adapted from Karnani, 2011)

Some authors have only implicitly mentioned the role of marginalised people as consumers (e.g. Amir, 2004; Viswanathan et al., 2011), whereas others have explicitly considered this role (e.g. Jagtap and Larsson, 2013). For instance, Mattson and Wood (2014), explicitly mention: "The term product is used in this paper to describe any consumer good that is purchased by an individual or household." Overall, the literature reports a wide range of cases and examples of products for selling to marginalised people, but there is a lack of operational guidance on how to include a wider range of aspects (e.g. financial sustainability, business models, etc.) essential to design and sell such products to poor people in a financial sustainable manner.

\subsection{As producers}

The people living in marginalised sections of societies in developing countries may engage in producing goods such as handicrafts, furniture and common household products. Such activities of producing goods play an important role in reducing poverty, providing them opportunities of income generation. Whilst majority of the articles consider the poor as product consumers, some have considered their role as producers. Some articles report development of methods to support the design practice of poor people so that they can create products that are new and more desirable to the consumers in potential markets, thereby increasing product sale and their income. Such studies thus focus on enhancing capability of marginalised producers to design products. Factors that promote adoption of design methods are also taken into account (e.g. Jagtap et al., 2014b), e.g. skill and literacy level of poor people as well as other attributes of the context in which they design and produce products. For instance, Girón et al. (2004), using participatory methods, developed a product design methodology for the craftswomen in resource limited societies, while considering their social, economic and cultural background. The developed methodology, specifically tailored to the needs of the craftswomen, allowed them to explore market needs, generate ideas and concepts, and test the developed concepts in potential markets. The methodology supported the women to design new products - the study mentions that the women designed 85 new types of products. Likewise, Kang (2016) presents participatory action research with a community of ceramic potters, aimed at enhancing production and trade of their products. Their action research involved: understanding the expectations of the potters and the circumstances in which they work, developing mood boards, generating ideas and concepts of ceramic products, developing prototypes, identifying trends, and reflecting on the design process and its outcomes. While the above 
studies were aimed at supporting design capability of the marginalised producers, Austin-Breneman and Yang (2013) proposed guidelines to design products for micro-entrepreneurs in resource limited societies. An example of this type of product is a drip irrigation system for low-income farmers. The guidelines for designing products specifically for micro-entrepreneurs in developing countries are, among others, designing for their business plan, and designing for maintainability, reliability and multifunctionality. While Kang (2016) and Girón et al. (2004) developed the methods in collaboration with the marginalised producers, Austin-Breneman and Yang (2013) developed their guidelines based on the published literature and interviews with the related experts.

In addition to the studies that have developed or proposed methods to support design capability of disadvantaged producers, some studies report on providing them designs which they can simply produce and sell to enhance their profits. Such designs, for instance, are given to them by design academics, professionally trained designers, or design students. Thomas (2006) presents an example of jute bags designed or commissioned by importers and produced by poor women in developing countries. The manufactured bags are then sold in developed countries via channels such as People Tree which is an online fair-trade retailer of clothes. While the market size of such products can be small, the income generated can be highly crucial and life-changing for poor people. Another example is a co-creation where design students worked collaboratively with marginalised waste collectors to design products from waste material to enhance value and generate additional income opportunities for those waste collectors (Thomas, 2006).

Another group of studies has undertaken empirical research to develop an understanding of the design practice of marginalised producers, with identification of barriers in their design practice. Donaldson (2006) carried out empirical research in Kenya to examine product design practice in a range of sectors, including that of producers operating in resource limited settings. She identified four product categories: imported products, copying designs, basic original design and speciality design. Many designs originated outside Kenya or were copied from imported products. She also observed more emphasis on detail design and manufacturing, with lack of attention to early phases of design process (e.g. identification and analysis of needs, concept generation, etc.). She also reported barriers in their design practice such as state corruption and limited physical infrastructure. Entrepreneurial activities of marginalised people in developing countries are usually hindered by lack of specialised knowledge and skills (Banerjee and Duflo, 2007). Product imitation, as found in Donaldson's (2006) study in Kenya, has also been identified by Thomas (2006) in Zimbabwe. Guimarges et al.'s (1996) study of the small enterprises in Brazil also observed little or no original design of products, with lack of employing formal design methods and tools in almost all enterprises in the study. On the other hand, the ability of marginalised producers to design products, for instance, in the form of redesigning an existing product to enhance its quality or designing tools and equipment for own use, is demonstrated in some other studies, e.g. Sverrisson's (1990) study in woodworking enterprises in Kenya and Chuta and Liedholm's (1985) survey in Sierra Leone. This suggests that marginalised people with no formal training in designing products can possess ability to design new products, but it appears that their design ability might be suppressed by the constraints they face or circumstances in which they produce goods.

People living in resource limited societies in developing countries may work in formal or informal sector. In the case of formal sector, a worker has an official contract with his or her employer, gets guaranteed fixed salary, and has a social security for health and other risks. On the other hand, a worker in the informal sector has no official contract with his or her employer, has no safe or organised work conditions, generally earns hand to mouth, gets irregularly paid, has no regular hours of work, and has no access to social security system (Schneider and Enste, 2013; Williams et al., 2015). Donaldson (2006) examined many characteristics of design practice in informal and formal sector in Kenya. For instance, there is a wide variation in technical and managerial skills of producers in both these sectors, they do not engage in prototyping or tinkering due to costs and available resources, they receive input material of inconsistent and poor quality, and they routinely recycle and reuse materials. When compared to formal sector, the quality of products in informal sector is low. The production of goods in informal sector is labour-intensive, relying on locally available materials and resources (e.g. Bhalla, 1989).

While Donaldson (2006) and Thomas (2006) provide details of the sector (e.g. formal or informal) that they examined, several articles do not provide any information about the type of sector (e.g. Murcott, 
2007; Crabbe, 2012; Kang, 2016), making it difficult to know sector-type in their studies. The type of sector is only implicitly mentioned in Guimarges et al.'s (1996) article; for instance, one of the keywords of their article is 'informal sector'. In a similar vein, Austin-Breneman and Yang (2013), about their study related to micro-entrepreneurs in developing countries, mention the sector type only in their literature review. In addition to the diversity in providing information on the sector type, there is a greater range in providing information on the firm size, e.g. number of marginalised people working in firms. For example, Donaldson's (2006) study was carried out in many types of firms- micro, small, medium and large, and Austin-Breneman and Yang's (2013) study is about micro-enterprises. The number or people in the firms surveyed by Guimarges et al. (1996) ranged between one to eleven. Again, many articles do not offer information on the firm size (e.g. Thomas, 2006; Murcott, 2007; Kang, 2016), making it difficult to gain an understanding of the context in which the disadvantaged people produced goods.

\subsection{As co-designers}

Co-design between designers and community members is crucial to alleviate cultural, social and knowledge differences between them (Sanders and Stappers, 2008). There are two ways of designing products for marginalised people in developing countries (Avgerou, 2010). First involves designing products outside the context of resource limited communities, in developed countries or in affluent and literate parts of developing countries, and then making these products available in the marginalised communities. Such designs which are remotely developed and just implemented in the communities often fail to achieve intended impact when the designers and implementers leave the community or start working on other projects (e.g. Nieusma, 2004; Thomas, 2006; Murcott, 2007; Ashraf et al., 2008; Dodson et al., 2012). Second approach is socially embedded, and involves marginalised communities in the design process, ensuring necessary understanding of the context in which the products and technologies are finally implemented (Dearden and Rizvi, 2008). Such co-design activities are crucial, suggesting designers to look beyond technological and engineering aspects of product design to the social and cultural context of marginalised communities (Rivett et al., 2014). Several authors have argued for co-designing with disadvantaged communities in all phases of the design process (e.g. Amir, 2004; Murcott, 2007; Viswanathan et al., 2011).

Some studies report design projects involving co-design with poor people, mentioning benefits associated with co-design (e.g. Sethia, 2005). Co-design assists both designers and community members (Mattson and Wood, 2014). For example, it supports designers in gaining knowledge about the needs, preferences, life circumstances and aspirations of people living in marginalised communities. Co-design also enhances designer's understanding of the resource limited setting in which the finally developed product is used. Furthermore, co-design is beneficial for the marginalized people. For instance, it empowers them to participate in co-design or related participatory activities, and can potentially support them in developing or enhancing their design capability. Co-design activities enhance the project ownership of marginalised communities, improving acceptance and adoption of products and technologies (Champanis and Rivett, 2012; Ssozi-Mugarura et al., 2017).

Whilst the above studies mention benefits of co-design for designers as well as marginalised communities, some studies elaborate on co-design activities and experiences. Thomas (2006), for example, presents a case about the design of a pedal-powered machine to reduce drudgery of washerwomen. Participatory activities with the washerwomen allowed designers to gain crucial insights into their difficulties and problems, suggesting their priority for income generation over health-related benefits. The pedal-powered machine was designed participatorily, considering suggestions and improvements recommended by the washerwomen. In a similar fashion, Nieusma and Riley (2010) present participatory workshops employed in designing a renewable energy system targeted for a rural community. Hussain et al. (2012) present a field study involving co-design methods that were used to generate concepts for a prosthetic device for marginalised children, and Ambole et al. (2016) and SsoziMugarura et al. (2017) elaborate on co-design of a sanitation system and an ICT intervention to support water planning, respectively. In these studies, authors either facilitated or were involved in the co-design activities, and these projects were typically carried out for 'research' purposes. 
Another group of studies presents guidelines for undertaking co-design activities in marginalised communities in developing countries. A more adaptive and flexible mindset is necessary when codesigning with these communities, with recognition that co-designing with such communities is in different conditions than those in developed countries (e.g. Hussain et al., 2012). Designers ought to recognise that the marginalised people are experts in surviving in limited resource settings, and can have thorough understanding of local networks and available materials and resources (Murcott, 2007). Another crucial guideline is that designers must give priority to work with marginalised people than with those who have not experienced living in resource limited settings. People working in NGOs or academic institutes in developing countries generally lack experience of living in such marginal settings, and as such, they might not know the complex difficulties and challenges of life circumstance in these settings. Many authors advocate actively including poor people in all phases of the design process (Nieusma and Riley, 2010). Employing suitable ways of involving and communicating with marginalised communities supports co-design with them. Drawings, cartoon-strips, narrative ways and pictures can be used in co-designing with marginalised people (e.g. Costandius, 2012; Du Preez et al., 2015; Ambole et al., 2016). Overall, the literature argues for participatorily designing with the marginalised individuals. However, there is lack of information on how to carry out co-design in 'real' projects. Examples of collaboratively designed projects implemented in marginalised communities are scarce (Kolk et al., 2014), and this can be due to the lack of simple and easy-to-use methods to engage with marginalised communities in real projects, which are often constrained due to time and available resources (e.g. Nieusma and Riley, 2010).

\section{Discussion and ways forward}

Numerous design studies have been carried out to understand and support design in resource limited societies in developing countries. Knowledge about design in such contexts, characterised by many different opportunities and constraints, will support the design practice in this field by developing and evaluating appropriate design methods as well as planning for future scholarly exploration of this field. The literature reveals three roles of poor people - consumers, producers, and co-designers. Although the literature portrays a great diversity in addressing many different research questions in considering these roles, there are many areas that are still unexplored. Whilst such gaps in the literature might be considered as a matter of concern, they offer opportunities for further research in this field.

Although the literature suggests the need of designing appropriate business models to sell or provide products to the marginalised people in a financially sustainable way, there is a lack of practical guidance on how to design products and business models in a synergistic manner, while addressing other constraints in resource limited societies. Future research in this field may also gain by thorough examination of different roles of the poor people regarding their ability and potential to contribute to social and human development (e.g. Broman and Robèrt, 2017; Missimer et al., 2017), for example, by addressing basic needs, providing access to education, and enhancing participation of the poor people in social, cultural and political activities. Future research may also compare approaches that aim at development of the poor or consider them as consumers for making profits. In addition, further research can aim at studying design projects undertaken by students, businesses, NGOs, and governments to identify links (if any) between such projects and corresponding roles of poor people, for example, future research may examine whether design projects carried out by NGOs frequently involve marginalised people as co-designers than those carried out by businesses. Further research can also aim at identifying types of design projects that thoroughly consider local context or involve local experts in the design process.

The literature has provided some insights into the design practice of underprivileged people. These insights are mostly gleaned by using retrospective methods such as interviews or analysis of secondary data. Future research can aim at understanding nuances of their design practice by using real time methods such as observations or think aloud protocol analysis, while complementing current retrospective methods. Furthermore, future research can also benefit from developing and evaluating design methods, grounded in social and cultural context of marginalised producers, to enhance their design capability or to support them in early phases of the design process in activities such as needs 
identification, concept generation and prototyping. This review also shows that future studies ought to report details such as type of sector (e.g. formal or informal), firm size, etc.

Although the literature argues for co-designing with marginalised communities, the examples of collaboratively designed and implemented 'real' design projects are scarce. The term 'real' design project refers to the projects undertaken for the purpose of implementing the outcome of the project, e.g. projects undertaken by NGOs, businesses, or governments with the aim of implementing the designed product or technology to support social or human development of the marginalised people. These projects, unlike academic projects typically undertaken by students or researchers, do not just end after the conceptual or prototyping phase, but rather require downstream planning, development and implementation. Since real design projects are often constrained due to available resources, future research in this field can gain from developing and evaluating co-design methods taking into account practicalities of expediency and other constraints in real projects, resulting into co-design methods that can be easily and efficiently deployed. This necessitates gaining an in-depth understanding of barriers and enablers in undertaking co-design with a range of stakeholders, including, among others, marginalised individuals, NGOs, and local governments. In addition, there is a need to develop gendersensitive co-design methods. Women living in poverty excessively suffer many problems as compared to men living in poverty, with differences in their needs and perspectives on problems they encounter (Kabeer, 1996; Cagatay, 1998). This implies that design research in this field can benefit from developing gender sensitive co-design approaches, which can facilitate more effective engagement of women in co-design activities. We believe that this review of the roles of marginalised people will support design researchers to investigate suggested avenues, as they are crucial for education, research and practice of design in this field. For example, development and evaluation of easy-to-use and efficient co-design methods can support not only real design projects, but can also aid design education as students can benefit from using such co-design methods.

\section{Acknowledgment}

This research received financial support from the Swedish Knowledge and Competence Development Foundation through the Model Driven Development and Decision Support research profile at BTH, Sweden.

\section{References}

Agnihotri, A. (2015), "Low-cost innovation in emerging markets”, Journal of Strategic Marketing, Vol. 23 No. 5 , pp. 399-411. http://doi.org/10.1080/0965254X.2014.970215

Akubue, A. (2000), "Appropriate Technology for Socioeconomic Development in Third World Countries", The Journal of Technology Studies, Vol. 26 No. 1, pp. 33-43. http://doi.org/10.21061/jots.v26il.a.6

Ambole, L.A., Swilling, M. and M'Rithaa, M.K. (2016), "Designing for informal contexts: A case study of Enkanini sanitation intervention", International Journal of Design, Vol. 10 No. 3, pp. 75-84.

Amir, S. (2004), "Rethinking design policy in the third world", Design Issues, Vol. 20 No. 4, pp. 68-75. http://doi.org/10.1162/0747936042311995

Angelin, A.H., Johansson, H. and Koch, M. (2014), "Patterns of institutional change in minimum income protection in Sweden and Germany", Journal of International and Comparative Social Policy. Vol. 30 No. 2 , pp. 165-179. http://doi.org/10.1080/21699763.2014.937584

Aranda Jan, C.B., Jagtap, S. and Moultrie, J. (2016), "Towards a framework for holistic contextual design for lowresource settings", International Journal of Design, Vol. 10 No. 3, pp. 43-63.

Ashraf, M., Swatman, P. and Hanisch, J. (2008), "An Extended Framework to Investigate ICT Impact on Development at the Micro (Community) Level", Proceedings of the European Conference on Information Systems (ECIS), Galway, Ireland, June 9-11, 2008.

Austin-Breneman, J. and Yang, M. (2013), "Design for micro-enterprise: an approach to product design for emerging markets", Proceedings of the 25th International Conference on Design Theory and Methodology, Portland, OR, USA, August 4-7, 2013, pp. V005T06A042. http://doi.org/10.1115/DETC2013-12677

Avgerou, C. (2010), "Discourses on ICT and Development”, ITID, Vol. 6 No. 3, pp. 1-18.

Banerjee, A.V. and Duflo, E. (2007), "The economic lives of the poor", Journal of Economic Perspectives, Vol. 21, pp. 141-167. http://doi.org/10.1257/089533007780095556

Baumgartner, J., Murcott, S. and Ezzati, M. (2007), "Reconsidering Appropriate Technology: The Effects of Operating Conditions on the Bacterial Removal Performance of Two Household Drinking-Water Filter 
Systems", Environmental Research Letters, Vol. 2 No. 2, pp. 1-6. http://doi.org/10.1088/17489326/2/2/024003

Bhalla, A. (1989), "Innovations and small producers in developing countries", Economic and Political Weekly, Vol. 24 No. 8.

Broman, G.I. and Robèrt, K.H. (2017), “A framework for strategic sustainable development”, Journal of Cleaner Production, Vol. 140, pp. 17-31. http://doi.org/10.1016/j.jclepro.2015.10.121

Buse, K., Hein, W. and Drager, N. (2009), Making Sense of Global Health Governance: A Policy Perspective, Palgrave Macmillan UK.

Cagatay, N. (1998), Gender and poverty, UNDP, Social Development and Poverty Elimination Division.

Cai, J., Yang, D. and Li, D. (2007), "Designing the right IT services for the bottom of the pyramid", Communications of the Association for Information Systems, Vol. 19 Article 22.

Champanis, M. and Rivett, U. (2012), "Reporting Water Quality: A Case Study of a Mobile Phone Application for Collecting Data in Developing Countries", Proceedings of the Fifth International Conference on Information and Communication Technologies and Development (ICTD'12), Atlanta, GA, USA, March 12-15, 2012, ACM, New York, pp. 105-114. http://doi.org/10.1145/2160673.2160688

Chuta, E. and Liedholm, C. (1985), Employment and growth in small-scale industry; empirical evidence and policy assessment from Sierra Leone, A study prepared for the ILO within the framework of the World Employment Programme.

Costandius, E. (2010), "Using art as a medium to enhance social responsibility and citizenship", Discourse and Communication for Sustainable Education, Vol. 1 No. 2, pp. 74-81. http://doi.org/10.2478/dcse-2013-0016

Crabbe, A. (2012), "Three strategies for sustainable design in the developing world", Design Issues, Vol. 28 No. 2, pp. 6-15. http://doi.org/10.1162/DESI_a_00139

Cunha, M.P., Rego, A., Oliveira, P., Rosado, P. and Habib, N. (2014), "Product Innovation in Resource-Poor Environments: Three Research Streams”, Journal of Product Innovation Management, Vol. 31 No. 2, pp. $202-$ 210. http://doi.org/10.1111/jpim. 12090

De Mel, S., McKenzie, D. and Woodruff, C. (2012), "One-time transfers of cash or capital have long-lasting effects on microenterprises in Sri Lanka", Science, Vol. 335 No. 6071, pp. 962-966. http://doi.org/10.1126/science.1212973

Dearden, A. and Rizvi, H. (2008), "Participatory IT Design and Participatory Development: A Comparative Review", Proceedings of the Tenth Anniversary Conference on Participatory Design 2008 (PDC '08), Bloomington, IN, USA, October 1-4, 2008, pp. 81-91.

Dodson, L., Sterling, S. and Bennett, J. (2012), “Considering Failure: Eight Years of ITID Research”, Proceedings of the Fifth International Conference on Information and Communication Technologies and Development (ICTD'12), Atlanta, GA, USA, March 12-15, 2012, ACM, New York, pp. 56-64. http://doi.org/10.1145/2160673.2160681

Donaldson, K. (2009), "The future of design for development: three questions", Information Technologies \& International Development, Vol. 5 No. 4, pp. 97-100.

Donaldson, K.M. (2006), "Product design in less industrialized economies: constraints and opportunities in Kenya", Research in Engineering Design, Vol. 17 No. 3, pp. 135-155. http://doi.org/10.1007/s00163-0060017-3

Du Preez, V., Cilliers, R., Chueng-Nainby, P. and Miettinen, S. (2015), Exploring context and building empathy with the youth in Southern Africa. [online] Nordes. Available at: http://www.nordes.org/opj/index.php/n13/article/download/407/384

Falcioni, J. (2011), "Research in Extreme Affordability", Mechanical Engineering-CIME, Vol. 133 No. 5, pp. 6-7.

Girón, J.D.L.P., Domínguez Hernández, M.L. and Jiménez Casta-eda, J.C. (2004), "Participatory methodologies and the product development process: the experience of Mixtec craftswomen in Mexico", Development in Practice, Vol. 14 No. 3, pp. 396-406. http://doi.org/10.1080/0961452042000191213a

Guimarges, L.E., Penny, J.E. and Moody, S. (1996), "Product design and social needs: the case of North-East Brazil”, International Journal of Technology Management, Vol. 12 No. 7-8, pp. 849-864.

Hussain, S. (2010), "Empowering marginalised children in developing countries through participatory design processes", CoDesign, Vol. 6 No. 2, pp. 99-117. http://doi.org/10.1080/15710882.2010.499467

Hussain, S., Sanders, E.B.N. and Steinert, M. (2012), "Participatory design with marginalized people in developing countries: Challenges and opportunities experienced in a field study in Cambodia", International Journal of Design, Vol. 6 No. 2, pp. 91-109.

Jagtap, S. and Kandachar P. (2010), "Representing Interventions from the Base of the Pyramid", Journal of Sustainable Development, Vol. 3 No. 4, pp. 58-73. http://doi.org/10.5539/jsd.v3n4p58

Jagtap, S. and Larsson, A. (2013), "Design of Product Service Systems at the Base of the Pyramid", ICoRD'13. Lecture Notes in Mechanical Engineering, Springer India, pp. 581-592. http://doi.org/10.1007/978-81-322$1050-4 \quad 46$ 
Jagtap, S., Larsson, A. and Kandachar, P. (2013), "Design and development of products and services at the Base of the Pyramid: a review of issues and solutions", International Journal of Sustainable Society, Vol. 5 No. 3 , pp. 207-231. http://doi.org/10.1504/IJSSOC.2013.054712

Jagtap, S., Larsson, A., Hiort, V., Olander, E., Warell, A. and Khadilkar, P. (2014a), "How design process for the Base of the Pyramid differs from that for the Top of the Pyramid", Design Studies, Vol. 35 No. 5, pp. 527-558. http://doi.org/10.1016/j.destud.2014.02.007

Jagtap, S., Warell, A., Hiort, V., Motte, D. and Larsson, A. (2014b), "Design methods and factors influencing their uptake in product development companies: A review", Proceedings of the 13th International Design Conference (DESIGN 2014), Dubrovnik, Croatia, May 19-22, 2014, The Design Society, Glasgow, pp. 231-240.

Jiehui, J. and Kandachar, P. (2008), "New market, new challenge, new opportunity (1) -Overview of China rural healthcare \& design methodology", 30th Annual International Conference of the IEEE Engineering in Medicine and Biology Society, IEEE, pp. 1579-1582. http://doi.org/10.1109/IEMBS.2008.4649473

Kabeer, N. (1996), “Agency, well-being \& inequality: Reflections on the gender dimensions of poverty", IDS bulletin, Vol. 27 No. 1, pp. 11-21. http://doi.org/10.1111/j.1759-5436.1996.mp27001002.x

Kang, L. (2016), "Social design as a creative device in developing Countries: The case of a handcraft pottery community in Cambodia", International Journal of Design, Vol. 10 No. 3, pp. 65-74.

Karelis, C. (2007), The Persistence of Poverty: Why the Economics of the Well-off Can't Help the Poor, Yale University Press, New Haven and London.

Karnani, A. (2007), "Misfortune at the bottom of the pyramid", Greener Management Journal, Vol. 51, pp. 99-110.

Karnani, A. (2011), Fighting poverty together-Rethinking strategies for business, governments, and civil society to reduce poverty, Palgrave Macmillan, New York, NY.

Kolk, A., Rivera-Santos, M. and Rufín, C. (2014), "Reviewing a decade of research on the "base/bottom of the pyramid" (BOP) concept", Business \& Society, Vol. 53 No. 3, pp. 338-377. http://doi.org/10.1177/0007650312474928

Manen, S., Avard, G. and Martinez-Cruz, M. (2015), "Co-ideation of disaster preparedness strategies through a participatory design approach: Challenges and opportunities experienced at Turrialba volcano, Costa Rica", Design Studies, Vol. 40, pp. 218-245. http://doi.org/10.1016/j.destud.2015.06.002

Margolin, V. (2007), "Design for Development: Towards a History”, Design Studies, Vol. 28, pp. 111-115. http://doi.org/10.1016/j.destud.2006.11.008

Marmot, M., Friel, S., Bell, R., Houweling, T.A., Taylor, S., (2008), "Closing the gap in a generation: health equity through action on the social determinants of health", The Lancet, Vol. 372 No. 9650, pp. 1661-1669. http://doi.org/10.1016/S0140-6736(08)61690-6

Mattson, C.A. and Wood, A.E. (2014), "Nine principles for design for the developing world as derived from the engineering literature", Journal of Mechanical Design, Vol. 136 No. 12, pp. 121403. http://doi.org/10.1115/1.4027984

Missimer, M., Robèrt, K.H. and Broman, G. (2017), “A strategic approach to social sustainability-Part 2: a principle-based definition", Journal of Cleaner Production, Vol. 140, pp. 42-52. http://doi.org/10.1016/j.jclepro.2016.04.059

Murcott, S. (2007), "Co-evolutionary design for development: influences shaping engineering design and implementation in Nepal and the global village", Journal of International Development, Vol. 19 No. 1, pp. 123-144. http://doi.org/10.1002/jid.1353

Murphy, H.M., McBean, E.A. and Farahbakhsh, K. (2009), “Appropriate technology-A comprehensive approach for water and sanitation in the developing world", Technology in Society, Vol. 31 No. 2, pp. 158-167. http://doi.org/10.1016/j.techsoc.2009.03.010

Narayan, D., Chambers, R., Shah, M.K. and Petesch, P. (2000), Voices of the Poor: Crying Out for Change, The World Bank - Poverty Division (PRMPO), New York.

Nielsen, B. and Santos, A.L.R. (2013), "Key challenges of product development for humanitarian markets", Global Humanitarian Technology Conference, IEEE, pp. 411-415. http://doi.org/10.1109/GHTC.2013.6713721

Nielsen, C. and Samia, P.M. (2008), "Understanding key factors in social enterprise development of the BOP: A systems approach applied to case studies in the Philippines", Journal of Consumer Marketing, Vol. 25, pp. 446-454. http://doi.org/10.1108/07363760810915662

Nieusma, D. (2004), “Alternative design scholarship: Working toward appropriate design”, Design Issues, Vol. 20 No. 3, pp. 13-24. http://doi.org/10.1162/0747936041423280

Nieusma, D. and Riley, D., (2010), "Designs on Development: Engineering, Globalization and Social Justice", Engineering Studies, Vol. 2 No. 1, pp. 29-59.

Papanek, V.J. (1972), Design for the real world, Thames and Hudson, London.

Prahalad, C.K. (2004), The fortune at the Bottom of the Pyramid: Eradicating poverty through profits, Wharton School Publishing Upper Saddle River, NJ. 
Prahalad, C.K. and Hart, S. (1999), Strategies for the bottom of the pyramid: Creating sustainable development (Working paper). [online] University of Michigan. Available at: http://www.bus.tu.ac.th/usr/wai/xm622/conclude\%620monsanto/strategies.pdf

Prahalad, C.K. and Lieberthal, K. (1998), “The end of corporate imperialism”, Harvard Business Review, Vol. 76 No. 4, pp. 68-79.

Radjou, N., Prabhu, J. and Ahuja, S. (2012), Jugaad innovation: Think frugal, be flexible, generate breakthrough growth, Wiley, New York, NY.

Ramachandran, D., Kam, M., Chiu, J., Canny, J. and Frankel, J.F. (2007), "Social dynamics of early stage codesign in developing regions", Proceedings of the CHI conference on Human Factors in Computing Systems (CHI '07), San Jose, CA, USA, April 30-May 3, 2007, ACM, New York, pp. 1087-1096. http://doi.org/10.1145/1240624.1240790

Rivett, U., Marsden, G. and Blake, E. (2014), "ICT for Development: Extending Computing Design Concepts", In: Cooper, B. and Morrell, R. (Eds.), Africa-Centred Knowldges: Crossing Fields and Worlds, Boydell \& Brewer Ltd, Suffolk, pp. 126-141.

Rodriguez, J., Diehl, J.C. and Christiaans, H. (2006), "Gaining insight into unfamiliar contexts: A design toolbox as input for using role-play techniques", Interacting with computers, Vol. 18 No. 5, pp. 956-976. http://doi.org/10.1016/j.intcom.2006.05.007

Rohwedder, W.J. (1987), Appropriate technology in transition: an organizational analysis, PhD thesis, University of California, Berkeley.

Schneider, F. and Enste, D.H. (2013), The shadow economy: An international survey, Cambridge University Press. http://doi.org/10.1017/CBO9781139542289

Schumacher, E.F. (1973), Small is beautiful: economics as if people mattered, Harper and Row, New York.

Sen, A. (1999), Development as freedom, Oxford Paperbacks.

Sethia, N. (2005), "At the bottom of the pyramid: Responsible design for responsible business", Design Management Review, Vol. 16 No. 3, pp. 42-49. http://doi.org/10.1111/j.1948-7169.2005.tb00202.x

Simon, H.A. (1996), The Sciences of the Artificial, MIT press, Cambridge, MA.

Ssozi-Mugarura, F., Blake, E. and Rivett, U. (2017), "Codesigning with communities to support rural water management in Uganda”, CoDesign, Vol. 13 No. 2, pp. 110-126. http://doi.org/10.1080/15710882.2017.1310904

Sverrisson, A. (1990), Research Policy Studies Discussion Paper Vol. 186 - Entrepreneurship and industrialization: A case study of carpenters in Mutare, Zimbabwe, Research Policy Institute, University of Lund, Sweden.

Thomas, A. (2006), "Design, poverty, and sustainable development”, Design Issues, Vol. 22 No. 4, pp. 54-65. http://doi.org/10.1162/desi.2006.22.4.54

Viswanathan, M. and Rosa, J.A. (2007), "Product and market development for subsistence marketplaces: Consumption and entrepreneurship beyond literacy and resource barriers", In: Cheng, J. and Hitt, M. (Eds.), Advances in international management series, Elsevier, Oxford, UK, pp. 1-17. http://doi.org/10.1016/S15715027(07)20001-4

Viswanathan, M. and Sridharan, S. (2012), "Product development for the BoP: Insights on concept and prototype development from university-based student projects in India", Journal of Product Innovation Management, Vol. 29 No. 1, pp. 52-69. http://doi.org/10.1111/j.1540-5885.2011.00878.x

Viswanathan, M., Yassine, A. and Clarke, J. (2011), "Sustainable product and market development for subsistence marketplaces: creating educational initiatives in radically different contexts", Journal of Product Innovation Management, Vol. 28 No. 4, pp. 558-569. http://doi.org/10.1111/j.1540-5885.2011.00825.x

Whitney, P. and Kelkar, A. (2004), "Designing for the Base of the Pyramid", Design Management Review, Vol. 15 No. 4, pp. 41-47. http://doi.org/10.1111/j.1948-7169.2004.tb00181.x

Wicklein, R.C. (1998), "Designing for appropriate technology in developing countries", Technology in Society, Vol. 20 No. 3, pp. 371-375. http://doi.org/10.1016/S0160-791X(98)00022-0

Williams, C.C., Shahid, M.S. and Martínez, A. (2015), "Determinants of the level of informality of informal microenterprises: some evidence from the city of Lahore, Pakistan”, World Development, Vol. 84, pp. 312-325. https://doi.org/10.1016/j.worlddev.2015.09.003

World Bank, (2010), World Development Indicators, World Bank Publications, Washington, DC.

Zeschky, M., Widenmayer, B. and Gassmann, O. (2011), "Frugal innovation in emerging markets", ResearchTechnology Management, Vol. 54 No. 4, pp. 38-45. http://doi.org/10.5437/08956308X5404007

Dr. Santosh Jagtap

Blekinge Institute of Technology, Product Development Research Lab

Blekinge Institute of Technology, 37179 Karlskrona, Sweden

Email: santosh.jagtap@bth.se 